\title{
Can feedstock production for biofuels be sustainable in California?
}

by Stephen R. Kaffka

The use of crops and crop residues as feedstocks for biofuels increases domestic and global supplies, creates new industries, and may result in reduced greenhouse-gas emissions. Uncertainty about the best crop and residue sources, technologies for manufacture, future public policy, and the global supply and price of oil make it difficult to predict the best approach. California growers can produce feedstocks from grain, oilseed and woody crops and, in the Imperial Valley, from sugar cane. If the technology for making ethanol or other liquid fuels from cellulose becomes cost-effective, then saline and other wastewaters may be used in biofuel feedstock production of salt-tolerant crops, particularly perennial grasses. However, recent global increases in biofuel production have raised questions about their impacts on food and feed prices, climate change and deforestation. New state laws affecting energy use and mandating greenhouse-gas reductions require that the sustainability of all biofuels be assessed. Sustainability should take into account factors at both the global and local scales, including resource-use efficiency, croppingsystem adaptability and the potential of biofuels to remediate agriculture's environmental effects.

U se of crops for biofuels has developed rapidly in the United States since the U.S. Congress passed federal energy bills emphasizing biomass in 2005 and 2007. The Energy Independence and Security Act (EISA 2007)

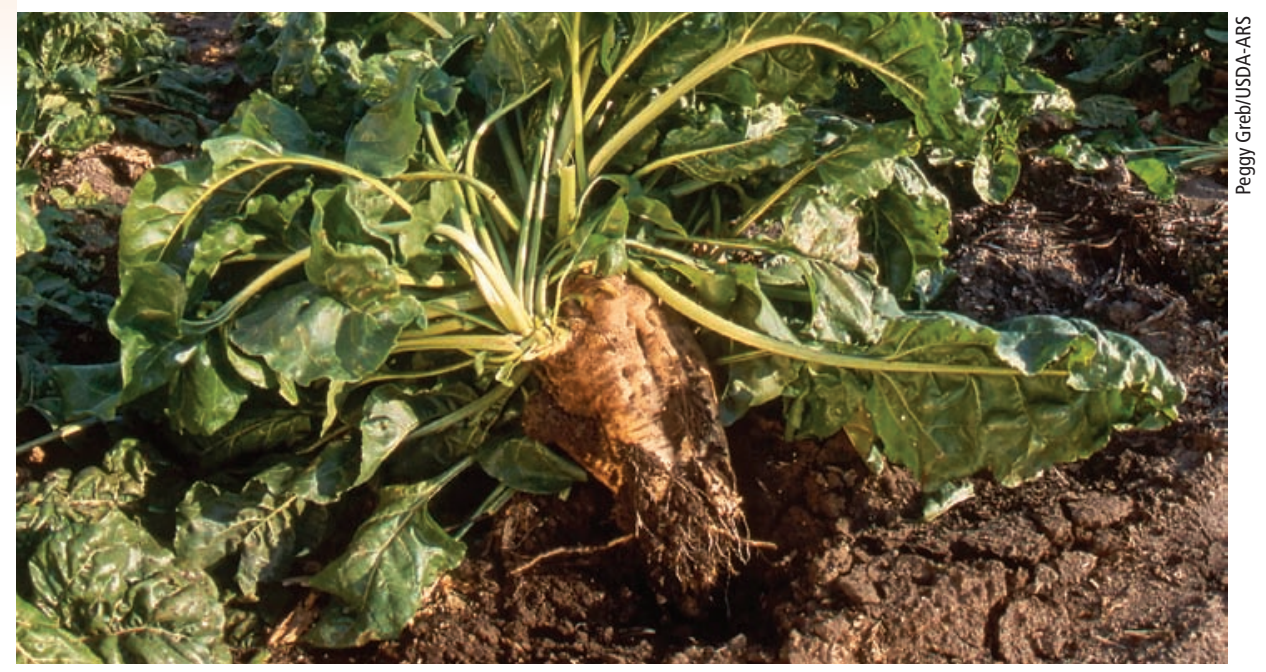

While corn grain has been the primary feedstock for ethanol in the United States, sugarbeets have a higher per-acre ethanol yield, especially given the high root yields achieved in recent years in California.

provides targets for bioenergy use in transportation and other sectors, and subsidies to increase the domestic manufacture and supply of ethanol and biodiesel for transportation. Current federal fuel mandates call for 15 billion gallons annually of corn ethanol, 1 billion gallons of biodiesel (primarily soy) and another 20 billion gallons from advanced (noncorn grain) biofuels, chiefly cellulosic sources.

California has mandated the use of alternative transportation fuels in AB32, the Global Warming Solutions Act of 2006 (CARB 2009a), and created guidelines for qualifying fuels through the Low Carbon Fuel Standard (LCFS) (CARB 2009b). The LCFS requires that greenhouse gases (GHG) from combusting petroleum-based transportation fuels decline over time, primarily through substitution and blending with less carbon-intensive alternative fuels, including those from biomass.

These and other policies have resulted in substantial investment in corn-grain-based ethanol manufacturing in the United States, although current economic conditions have slowed or idled new facilities. At the same time, oil price volatility makes investment in alternative biofuels uncertain. While price volatility will continue, the demand for corn grain for etha- nol likely will remain high as long as federal policies continue to encourage ethanol use and the price of oil is high (Tokgoz et al. 2007).

As petroleum reaches its practical limits, the importance of biomass as a transportation-fuel feedstock will increase. California scientists from UC and other institutions are now working to develop clear metrics and goals for sustainable biofuel production. This discussion has been spurred by the LCFS and subsequent California Air Resources Board resolution 09-31 (CARB 2009c), which call for — among other things - a science-based definition of sustainability, and provisions to incentivize sustainable fuels. The deadline for these provisions is December 2011.

\section{Evaluating agricultural efficiency}

The definition of "sustainability" in agriculture has been, and continues to be, the cause of much controversy and debate. Montieth (1990) formulated one of the simplest, most relevant ways to evaluate agricultural sustainability. His sustainability ideal is a farming system that creates ever-greater outputs for everfewer inputs on a per-unit product basis. An unsustainable situation occurs when inputs increase or are static as output declines. Increasing resource-use ef- 
ficiency, and sustainability, is correlated with a decline in cost per-unit product. Resource-use efficiency is important because it takes energy to produce energy crops. The larger the difference between the energy used for feedstocks and that returned from the feedstock, the greater the net energy yield. High-energy yield per acre of cropland is a critical factor affecting sustainability (Liska and Perrin 2009). Many of the adverse greenhousegas effects of current biofuel production are attributed to the crop production component (Zah et al. 2008). Acquiring crops and residues from fewer acres at high efficiency allows other agricultural lands to be used for conservation, as well as natural systems such as forests, which may also accumulate significant amounts of carbon (Robertson et al. 2000).

Research to support increasing agricultural efficiency, including new technologies such as precision agriculture (Kaffka et al. 2006) and reduced tillage (Mitchell 2009), remains essential (Alston and Zilberman 2003). The challenge is to achieve both efficient and low-polluting cropping systems, because intensive practices involving irrigation, fertilizer and pesticide use may be more damaging locally, even if large-scale resource-use efficiency is enhanced (de Wit 1992). Reconciling these concerns remains an open issue in developing performance standards for sustainable production, and is an essential objective for adaptive agricultural research.

California is the most productive agricultural state in terms of income, due to farmers' ability to produce diverse, high-value crops. In addition, the state has a nearly year-round, frost-free growing season, high levels of solar radiation, good soils, irrigation capacity (largely avoiding crop water stress), pest and disease management, and high yields. In the absence of water and nutrient stress, crop yields are limited primarily by solar radiation and tend to be more consistent than in rainfall-dependent areas. Because yields are high, efficiency also can be greater.

Data from California demonstrates this process. From 1950 to 1990, the productivity of field crops was estimated to increase by a factor of 2.4 while inputs increased by only about 0.6 . This increase was due more to technological change than to an increase in inputs, although both occurred. However, the rate of increase in crop productivity was less during the 1990-to-2002 period for most crops than it was elsewhere in the United States (Alston and Zilberman 2003).

\section{Defining sustainability}

Sustainability has many definitions, which usually include more than just efficiency considerations. Efforts are under way to develop practical standards to satisfy diverse aspects of sustainability. For about a decade after the oil shock of 1973, there was widespread discussion about energyuse efficiency in agriculture (Stanhill 1985). Since then, discussions have focused on soil quality, pesticide use, the relative benefits or disadvantages of organic farming, and social aspects of farming (Francis et al. 2007), as well as direct and indirect effects on global land use, greenhouse-gas emissions and other sustainability attributes.

The Biomass Roadmap prepared by the California Biomass Collaborative, to provide guidance on the sustainable development of biomass energy in California, calls for enforceable, performance-based standards that are locally relevant and internationally consistent (http://biomass.ucdavis.edu). New state laws like California's AB32 and AB118 (CEC 2009) support the development of alternative transportation fuels and include requirements to address and ensure sustainability.

Many groups around the world are writing sustainability standards for biofuel production (van Dam et al. 2008). Some are goal-proscribing and focus on motivating change, based on ideas about what would be best for agriculture (Francis et al. 2007). Other definitions are descriptive and focus on either the ability of agriculture to fulfill a set of goals or standards, or more simply on an agricultural system's ability to continue through time.

The Roundtable on Sustainable Biofuels (RSB 2009), a nonprofit based in Lausanne, Switz., recently published an updated draft of sustainability principles and criteria, derived from a broadly consultative process. The draft is an attempt to protect environmental conditions and human welfare as biofuels are brought into global trade and use, and to create international consensus. However, optimum or best management practices are locally developed and interact with highly diverse social circumstances, making the formulation of an international standard a formidable challenge. Also, since all agricultural systems lead to some level of ecosystem change, principles that minimize landscape alteration - or resource depletion - may inevitably stifle biofuel development.

Standards for energy crops must be based on a clear definition of sustainable agriculture. Hansen (1996) provided a still-useful categorization of differing definitions, arguing for (1) a literal definition of sustainability - the ability to continue over time, (2) the quantitative assessment of properties associated with sustain-

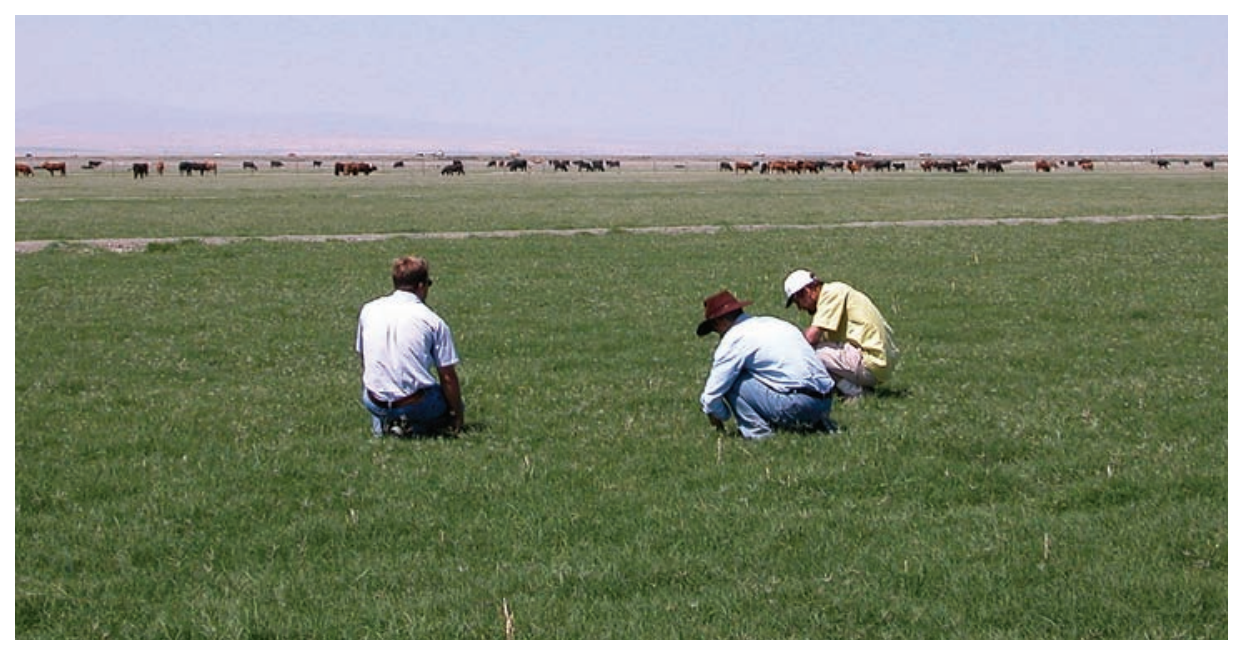

Some biofuel crops may help remediate environmental problems. UC researchers and a grower evaluate bermudagrass pastures in Kings County that were produced on saline soils and irrigated primarily with recycled, saline drainage water. 
ability, measured as continuous variables within well-defined systems and (3) an accounting for the variation that inevitably occurs with time.

Sustainability standards should include requirements for the measurement and prediction of relevant biophysical processes, such as changes in soil organic matter, crop yield and environmental effects. Agricultural research institutions are generally responsible for these measurements, not individual farmers or vendors. The best way to develop these measurements is dedicated, long-term research closely integrated with simulation modeling, but neither alone is sufficient (Tubiello et al. 2007). Specific measurements cannot define sustainability, but rather are objective considerations essential for its definition. Since the measurement of long-term trends and environmental effects is difficult and expensive, sufficient public support for high-quality agricultural research focused on these public objectives is necessary for regulatory programs to be effective.

Social and environmental concerns reflect the multiple roles played by agriculture in human society, but they are also difficult to define and measure (Francis et al. 2007). No one best policy can result from such considerations; diverse views about the character of the productive landscape, the appropriate place for wildlife, measurable and perceived consequences from pesticide use, and the distribution of benefits and costs must be considered. A dynamic, ongoing and broadly inclusive consultative process to guide public policy may be the only legitimate way to combine such considerations together with more quantitatively measurable phenomena.

Innovation occurs continuously in agriculture. Consequently, best man-

TABLE 1. Estimated average and range for energy return on investment (EROI)* of various biofuel feedstocks

\begin{tabular}{|c|c|c|c|c|c|}
\hline & $\begin{array}{l}\text { Corn } \\
\text { ethanol }\end{array}$ & $\begin{array}{c}\text { Sugar cane } \\
\text { ethanol }\end{array}$ & $\begin{array}{l}\text { Switchgrass } \\
\text { and other } \\
\text { cellulosic sources }\end{array}$ & Biodiesel & Petroleum $\dagger$ \\
\hline Average & 1.3:1 & $9: 1$ & $6: 1$ & $3: 1$ & $15: 1$ \\
\hline Range & $0.84-2.96$ & $6.0-11.0$ & $0.69-15.0$ & & \\
\hline \multicolumn{6}{|c|}{$\begin{array}{l}\text { Sources: Hammerschlag 2006; Cassman et al. 2007; Schmer et al. } 2008 . \\
\text { * EROI = Energy out/energy in (nonrenewable). The larger the EROI, the more } \\
\text { renewable energy is delivered per unit of fossil fuel used in its production. }\end{array}$} \\
\hline \multicolumn{6}{|c|}{$\begin{array}{l}\text { † Value for new petroleum recovery in the United States, from Cleveland (2005), } \\
\text { is provided for comparison. }\end{array}$} \\
\hline
\end{tabular}

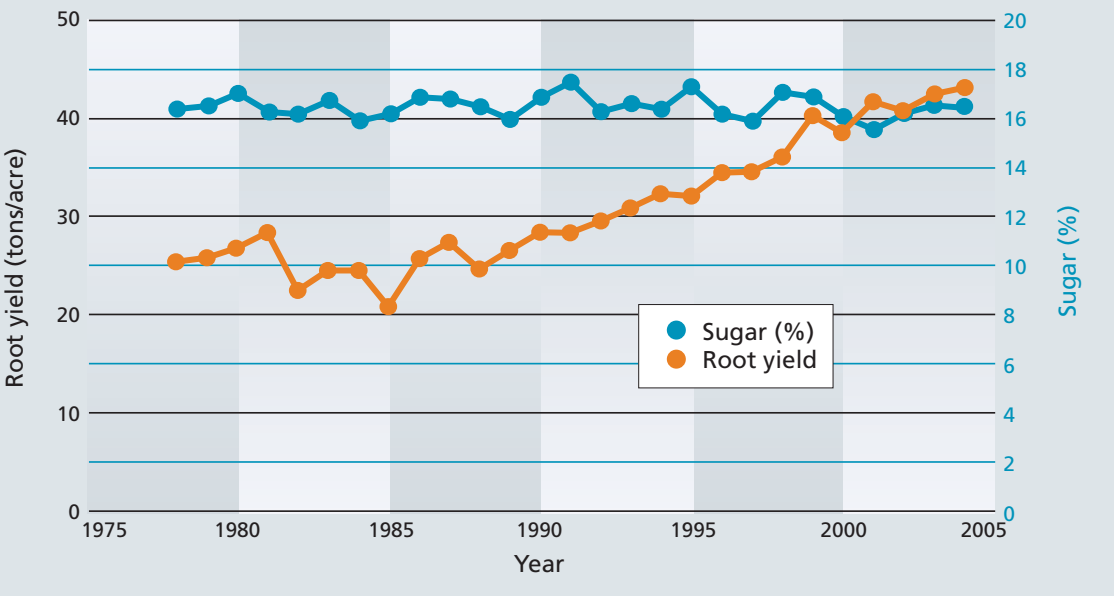

Fig. 1. Sugarbeet yield increases from 1978 to 2004. Data courtesy of California Beet Growers Association, Stockton, Calif.

agement practices constantly evolve in response to new research discoveries, technological advances and changing economic circumstances. To be useful, sustainability standards must account for and encourage innovation. The optimum mix of farming practices varies locally and is guided by applied research and farmer adaptation; one good example is the UC integrated pest management guidelines (UC IPM 2009), which are updated continuously. Rigid concepts of sustainability will stifle innovation, and lead to less-than-optimal management locally. In a fundamental and seemingly contradictory sense, sustainability involves flexibility and adaptation, that is, the ability to change. Achieving this is a significant challenge for the regulatory community.

\section{Best biomass crops and uses}

Which agricultural feedstocks will be best in the future remains uncertain, and a number are being investigated. Many analyses indicate that rather than grains or seeds, crop residues and purpose-grown crops that produce large amounts of biomass per acre will be more efficient and have the greatest environmental benefits (Schmer et al. 2008; Adler et al. 2007). Some estimates for the conversion of cellulosic feedstocks approach the efficiency of newly developed petro- leum supplies (table 1). But compared to calculations for grain, sugar and oilseed crops, biofuel yields from cellulosic sources are still theoretical and have not yet been realized commercially (Liska and Perrin 2009). It is difficult to break down tough, resistant, plant cell walls into sugars that can then be fermented into ethanol, other alcohols or carboxylic acids (US DOE 2006), and much related research and development is under way (see pages 178 and 185).

Biomass may also be an efficient petroleum substitute for uses other than transportation fuel. For example, Hermann et al. (2007) and Ragauskas et al. (2006) reported that bio-based bulk organic chemicals offer clear environmental and energetic advantages compared to petroleum as a feedstock. This comes in part from avoiding expensive oxygenation and catalytic steps to convert petroleum into alcohols, carboxylic acids and esters. About $5 \%$ of the petroleum entering a modern refinery goes toward the manufacture of such precursor chemicals (Ragauskas et al. 2006), and replacing this use of petroleum may be a more valuable use for biomass than producing transportation fuels. For both these markets, sourcing sufficient, reliable and sustainable supplies of feedstock is an essential but unmet challenge.

\section{Sustainable feedstocks}

Crops produced with increasing resource-use efficiency will be better candidates for biofuel feedstocks. For example, sugarbeets have been grown in California since 1870, and in recent years yields have risen substantially (fig. 1). With increased fertilizer efficiency, 
the Imperial Valley has had the highest sugarbeet yields globally for the last several years. In July 2007, Desert Sky Farms produced about 11 tons (22,000 pounds) of sugar per acre for a July-harvested field, substantial yield progress over the last decade. Researchers and farmers have learned that lower amounts of fertilizer nitrogen per unit yield can be used (fig. 2). Similar efficiency gains are needed if traditional crops are to be used for biofuels. In recent life-cycle comparisons of biofuel crops (Sharpouri et al. 2006; Zah et al. 2008), sugarbeets were among the most efficient ethanol feedstocks, even at much lower yields than in California.

Worldwide, the most important crops used for biofuel feedstocks are sugar cane (in Brazil and other tropical locations) and corn for ethanol, and oil palm, soybean and canola or rapeseed for biodiesel. Europeans also use wheat and sugarbeets for ethanol production. Soybeans are the principal crop feedstock used for biodiesel, followed by canola. Soybeans have never been produced on a commercial scale in California because older varieties were not well adapted to the state's climate, and because the value of the oil produced has been too low compared to other alternative crops. Canola grows well in California but is not widely produced here. It is reported to be a selenium accumulator and may help remediate selenium accumulation problems in San Joaquin Valley soils (Stapleton and Banuelos 2009). Like wheat, canola grows in the winter and can take advantage of winter rainfall, minimizing the need for irrigation.

The oilseed crop grown most widely in California for the last 60 years is safflower, which is well adapted to California's semiarid climate (Kaffka and Kearney 1998). Its fatty-acid composition makes it one of the most suitable oilseed feedstocks for biodiesel production using the fatty-acid methyl ester or FAME process, resulting in a high-quality biodiesel fuel. It is also relatively easy to grow and if irrigated properly does not have many pest or disease problems.

Finally, several groups are attempting to develop ethanol production from sugar cane in the Imperial Valley. Initial evaluations suggest that produc-

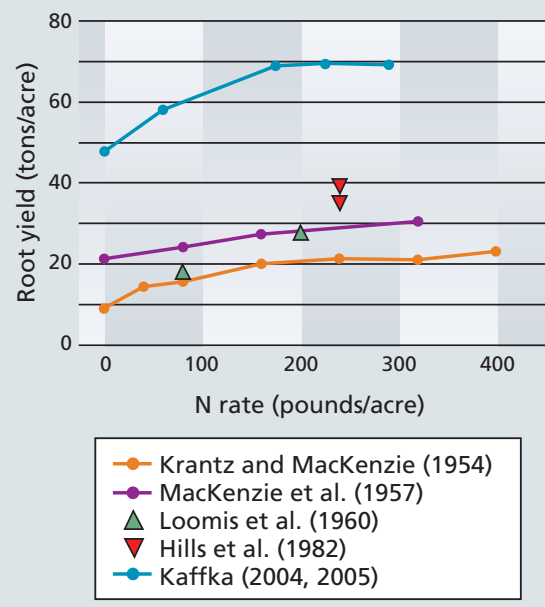

Fig. 2. Sugarbeet root yields and nitrogen fertilizer levels in a series of trials, 1954 to 2005, UC Desert Research and Extension Center, Holtville, Calif., and the author's research.

tivity will be high and water use will be approximately in line with that of alfalfa (Bazdarich and Sebasta 2001). Additional quantification is needed to substantiate these claims. If obstacles to its development can be overcome, sugar cane can provide ethanol for fuels, electricity from the combustion of residual biomass (bagasse) and other possible secondary products.

\section{Biofuels in agronomic systems}

There are concerns that biomass crops should be restricted because of an inherent conflict between their use for food or for fuels, especially affecting the poor (see page 191). A more useful way to think about the production of crops for energy, however, involves considering individual crops in cropping systems.

Biofuel feedstock crops can serve useful roles in California in rotation with other more valuable crops. For example, safflower may be the deepestrooting annual crop, allowing farmers to use water stored in well-drained soil from winter rainfall or the previous season's irrigation, and to recover nitrogen fertilizer from soils at greater depths than other crops (Bassil et al. 2002). Safflower is also moderately salttolerant, so it can be grown on soils with some salt limitations or partially irrigated with saline water (Bassil and Kaffka 2002a, 2002b).

In rotation with higher value crops that are not as deep-rooted such as tomatoes or cotton, safflower can remediate some environmental effects of intensive agriculture. Because nitrogen fertilizer is usually the most energyintensive input in crop production, this in turn improves the potential energetic efficiency of biodiesel made from safflower. Efficiencies of this sort are not recognized in large-scale surveys of costs and benefits (Zah et al. 2008).

More generally, diversifying cropping systems provides a number of agronomic and economic benefits. Since there is constant pressure for farms to specialize (de Wit 1992), biofuel crops may provide economic incentives to capture the positive agronomic benefits from more diverse cropping systems.

\section{Landscape-scale management}

Another way to think about efficiency is to consider potential biofuel crops at the regional landscape scale, where they may help manage environmental problems. Salts and salt disposal are a problem in all irrigated agricultural regions of the world with semiarid climates. In California, salinity is a particular problem in the western San Joaquin Valley, where naturally occurring salts and trace elements like selenium are mobilized and concentrated by irrigation practices (Stapleton and Banuelos 2009). Some fields in the region have been retired due to salt accumulation and a lack of sufficient water or drainage to sustain crop production. In addition, even irrigation at better locations produces salts that find their way into underlying aquifers (Schoups et al. 2005). Some crops can grow on salt-affected land or can use lower-quality water sources without yield losses, and could help intercept this saline drainage water.

Several perennial forage grasses in particular are salt-tolerant and easy to manage (Corwin et al. 2008). Various species have been suggested as good sources for cellulosic material for biofuel. Among the grasses, switchgrass is most commonly mentioned in the United States (Schmer et al. 2008). A perennial indigenous to large regions in the Plains states, switchgrass does not require annual tillage and planting, and is grown on conservation reserve lands that have uneconomic yields of annual crops or are too erosive. But variable climate in that part of the United States makes switchgrass supplies uncertain 


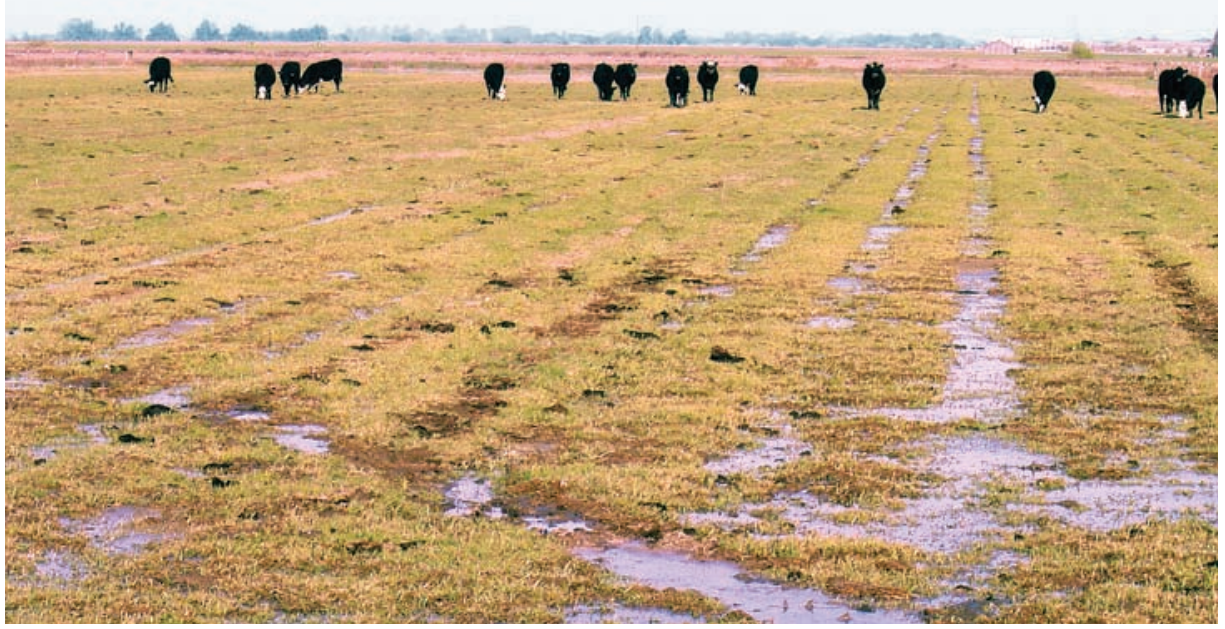

Cattle graze on a bermudagrass pasture grown on saline soils in Kings County; the fast-growing grass could also be harvested as a biomass feedstock if suitable markets were available nearby.

in dry years, potentially limiting production levels in biorefineries using it as a feedstock. In contrast, the production of a salt-tolerant perennial grass in California using moderately saline water for irrigation could provide reliable, predictable supplies of biomass to a factory sited near the point of production. If yields are high, the distance biomass must be moved would be reduced because the area needed to produce it would be smaller and biorefineries could be centrally located.

Likewise, the author and others (Corwin et al. 2008) have grown bermudagrass on a severely salt-affected site in Kings County since 1999, using a mixture of saline drainage water, wastewater from the town of Lemoore, and King's River irrigation water, while maintaining soil quality. This forage was grazed but could also be harvested as a biofuel feedstock, given suitable markets.

The use of saline land and water may seem like an exception to the idea that the most efficient response to inputs occurs on better quality land, and the most efficient use of agricultural inputs occurs at higher yield levels (de Wit 1992). But if a crop is unaffected or marginally affected by salinity because it is tolerant, or if it is produced when salt stress is reduced (winter production), then the crop's response to inputs could still be efficient (Bassil and Kaffka 2002a, 2002b). In these and other ways, biofuel cropping systems in California could help manage waste resources and related environmental problems, and improve overall system sustainability. Further, the cost of feedstock production is subsidized by reductions in the cost of managing related environmental problems.

\section{Reducing greenhouse gases}

Even if crop production is efficient, biofuels also should reduce the global warming potential of transportation fuel. Because fuel made from plant materials recycles atmospheric carbon dioxide captured by plants, biofuels can potentially reduce greenhouse gases (Farrell et al. 2006). However, more complete analysis may uncover effects that reduce or eliminate that benefit. The federal Renewable Fuel Standard specifies minimum levels of life-cycle greenhouse-gas emissions reductions for diverse types of biofuels (US EPA 2009). California's Low Carbon Fuel Standard also mandates reductions in such emissions through changes in the carbon intensity of fuels.

Life-cycle analysis calculates all the energy costs and benefits of a biofuel production process, from field to final use (Wang et al. 2007). Even the most careful life-cycle analysis, however, involves assumptions and decisions about qualitative criteria used in making quantitative assessments (Zah et al. 2008). Life-cycle analysis cannot anticipate future conditions and technical breakthroughs, so it is best used for comparison rather than setting absolute standards. Transparency and ease of use of life-cycle analysis models is needed to legitimize them as a basis for important public policy decisions (Liska and Perrin 2009).

A complete accounting of all greenhouse gases is required for life-cycle analysis. While crops absorb greenhouse gases, producing crops also generates them. Nitrogen fertilization results in increased nitrous oxide $\left(\mathrm{N}_{2} \mathrm{O}\right)$ emissions from soils. Because nitrous oxide has a global warming potential that is 297 times that of carbon dioxide, heavy use of nitrogen fertilizer with energy crops may in some cases negate the effects of atmospheric carbon uptake in the biomass. Nitrous oxide is one of the most important greenhouse-gas emissions from agriculture (Snyder et al. 2007), and there is significant uncertainty about its measurement (Adler et al. 2007; Snyder et al. 2007). High-quality agricultural research is also needed to ensure accurate analysis of the greenhouse-gas costs of biofuels.

\section{Implications for California biofuels}

The sustainable use of crops for biofuels will depend on ever-increasing efficiency in crop production and improving the returns for all energycontaining inputs in farming systems. Without this, there is no reasonable basis to use crops for biofuels. Similarly, adequate supplies of irrigation water are necessary for any crop production in California, including biofuel crops. Sustainability standards must include the measurement and robust prediction of trends in important biophysical characteristics of farming systems. Standards must account for and encourage — not inhibit — innovation, while seeking the least environmental perturbation. A means of valuing incommensurable social values must be included in the standard-setting process. Lastly, any useful sustainability standard for biofuel production from crops must include adequate investment in public agricultural research, and a continuous commitment to broadly inclusive consultative processes in setting and maintaining standards.

\section{Biofuel cropping systems in California could help manage waste resources and related environmental problems, and improve overall system sustainability.}


California's agricultural economy provides opportunities for biomass production, ranging from the largescale industrial production of energy crops such as sugar cane in the Imperial Valley and the use of salt-affected lands and saline water in the western San Joaquin Valley, to the smaller scale, integrated production of biomass to help meet individual on-farm energy

\section{References}

Adler, PA, del Grosso SJ, Parton WJ. 2007. Life-cycle assessment of net greenhouse-gas flux for bioenergy cropping systems. Ecol Applicat 17(3):675-91.

Alston J, Zilberman D. 2003. Science and technology (chapter 11). In: Seibert J (ed.). California Agriculture: Dimensions and Issues. Giannini Foundation, Davis, CA. p 257-87. http://giannini.ucop.edu/CalAgbook. htm

Bassil ES, Kaffka SR. 2002a. Response of safflower (Carthamnis tinctorious L.), to saline soils and irrigation. I. Consumptive water use. Agric Water Manage 54:67-80.

Bassil ES, Kaffka SR. 2002b. Response of safflower (Carthamnis tinctorious L.), to saline soils and irrigation. II. Crop response to salinity. Agric Water Manage 54:81-92.

Bassil ES, Kaffka SR, Hutmacher RB. 2002. Response of safflower (Carthamnis tinctorious L.) to residual soil $\mathrm{N}$ following cotton (Gossypium spp.) in rotation in the San Joaquin Valley of California. J Agric Sci 138:395-402.

Bazdarich M, Sebasta P. 2001. On the economic feasibility of sugar cane-to-ethanol operations in the Imperial Valley. UCR Forecasting Center, A. Gary Anderson Graduate School of Management and UC Desert

Research and Extension Center.

[CARB] California Air Resources Board. 2009a. AB32 Fact Sheet. Sacramento, CA. www.arb.ca.gov/cc factsheets/ab32factsheet.pdf

CARB. 2009b. Low Carbon Fuel Standard Program. Sacramento, CA. www.arb.ca.gov/fuels/lcfs/lcfs.htm (accessed 9/15/09)

CARB. 2009c. Resolution 09-31. Aug. 23, 2009. Sac ramento, CA. www.arb.ca.gov/regact/2009/lcfs09/ res0931.pdf.

[CEC] California Energy Commission. 2009. Develop ment of Regulations for the Alternative and Renewable Fuel and Vehicle Technology Program. Dock No 08-OIR-1. Sacramento, CA.

Cassman KG, Doberman A, Walters DT, Yang H. 2003. Meeting cereal demand while protecting natural resources and improving environmental quality. Ann Rev Env Resour 28:315-58.

Cleveland CJ. 2005. Net energy from oil and gas extraction in the United States. Energy 30:1769-82.

Corwin DL, Lesch SM, Oster JD, Kaffka SR. 2008. Short-term sustainability of drainage water reuse: Spatio-temporal impact on soil chemical properties. J Env Qual 37:S8-24.

de Wit CT. 1992. Resource use efficiency in agriculture. Agric Sys 40:125-51. demands. The amount and extent of potential biofuel production in California are difficult to predict because of uncertainty associated with changing technology and public policy. Foreseeable increases in the price of oil, regulatory requirements, increased efficiency in crop production and supportive standards will make possible the production of crops for biofuels in California.

[EISA] Energy Independence and Security Act. 2007. A Summary of Major Provisions. US Senate, Washington, DC. energy.senate.gov/public/_files/RL342941.pdf.

Farrell AE, Plevin RJ, Turner BT, et al. 2006. Ethanol can contribute to energy and environmental goals. Science 311:506-8.

Francis CA, Poincelot RE, Bird GW (eds.). 2007. Developing and Extending Sustainable Agriculture: A New Social Contract. New York: Haworth Pr. 367 p.

Hammerschlag R. 2006. Ethanol's energy return on investment: A survey of the literature: 1990-present. Env Sci Technol 40:1744-50.

Hansen JW. 1996. Is agricultural sustainability a useful concept? Agric Sys 50:117-43.

Hermann BG, Blok K, Patel MK. 2007. Producing biobased bulk chemicals using industrial biotechnology saves energy and combats climate change. Env Sci Technol 41:7915-21.

Hills FJ, Salisberry R, Ulrich A. 1982. Sugarbeet Fertilization. Bull 1891. UC DANR, Oakland, CA. 17 p.

Kaffka SR, Kearney TE. 1998. Safflower Production in California. 1998. UC DANR Spec Pub No 21565. Oakland, CA. 29 p.

Kaffka SR, Lesch SM, Bali KM, Corwin DL. 2006. Site-specific management in salt-affected sugar beet fields using electromagnetic induction. Comp Electronic Agric 46:329-50.

Krantz BA, Mackenzie AJ. 1954. Response of sugar beets to nitrogen fertilizer in the Imperial Valley, California. Vol III, Part 1. p 36-41. In: Proc of Eighth General meeting, ASSBT, Feb. 24-25, Denver, CO.

Liska A, Perrin RK. 2009. Land use emissions in the life cycle of biofuels: Regulations versus science. Biofuel Bioproduct Refining 3:318-28.

Loomis RS. Brickey FE, Broadbent FE, Worker GF. 1960. Comparisons of nitrogen source materials for midseason fertilization of beets. Agron J 53:97-101.

Mackenzie AJ, Stockinger KR, Krnatz BA. 1957. Growth and nutrient uptake of sugar beets in the Imperial Valley, California. J Am Soc Sugar Beet Tech IX(5):400-7.

Mitchell J. 2009. Conservation Tillage Work Group: Current Research Projects. http://ucce.ucdavis.edu/files/ filelibrary/5334/2290.pdf.

Monteith J. 1990. Can sustainability be quantified? Indian J Dryland Agric Res Develop 5(1-2):1-5.

Raguaskas AJ, Williams KK, Davison BH, et al. 2006. The path forward for biofuels and biomaterials. Science 311:484-9.

Robertson GP, Paul EA, Harwood RR. 2000. Greenhouse gases in intensive agriculture: Contributions of individual gases to radiative forcing of the atmosphere. Science 289:1922-5.
The best and most sustainable choices will be based on the interaction of these factors and locally varying production conditions.

S. Kaffka is Director, California Biomass Collaborative, and Extension Agronomist, Department of Plant Sciences, UC Davis.

[RSB] Roundtable on Sustainable Biofuels. 2009. The Roundtable on Sustainable Biofuels Announces New Governance System. Lausanne, Switz. http://cgse.epfl. ch/page65660.html.

Schmer MR, Vogel KP, Mitchell RB, Perrin RK. 2008. Net energy value of cellulosic ethanol from switchgrass. PNAS 105:464-9.

Schoups G, Hopmans JW, Young CA, et al. 2005. Sustainability of irrigated agriculture in the San Joaquin Valley, California. PNAS 102:15352-6.

Sharpouri H, Salassi M, Fairbanks JN. 2006. The Economic Feasibility of Ethanol Production from Sugar in the United States. USDA Office of Energy Policy and New Uses, Washington, DC.

Snyder CS, Bruulsema TW, Jensen TL. 2007. Best management practices to minimize greenhouse gas emissions associated with fertilizer use. Better Crop 91(4):16-8.

Stanhill G (ed.). 1985. Energy and Agriculture. Berlin, Germ.: Springer-Verlag. 192 p.

Stapleton JJ, Banuelos GS. 2009. Biomass crops can be used for biological disinfestation and remediation of soils and water. Calif Agric 63(1):41-6.

Tokgoz S, Elobeid A, Fabriosa J, et al. 2007. Emerging biofuels: Outlook of effects on U.S. grain, oilseed, and livestock markets. Staff Report 07-SR-101. Center for Agricultural and Rural Development. Iowa State University, Ames, lowa.

Tubiello FN, Soussana J-F, Howden SM. 2007. Crop and pasture response to climate change. PNAS 104:19686-90.

[UC IPM] UC Statewide Integrated Pest Management Program. 2009. Pest Management Guidelines. www. pm.ucdavis.edu.

[US DOE] US Department of Energy. 2006. Breaking the Biological Barriers to Cellulosic Ethanol: A Joint Research Agenda. DOE/SC-0095. www.doegenomes tolife.org/biofuels.

[US EPA] US Environmental Protection Agency. 2009 Regulation of Fuels and Additives: Changes to Renewable Fuel Standard Program; Proposed Rules. 40 CFR Part 80. Federal Register. May 26, 2009

van Dam J, Junginger M, Faaij A, et al. 2008. Overview of recent developments in sustainable biomass certification. Biomass Energy 32:749-80.

Wang M, May W, Huo H. 2007. Life-cycle energy and greenhouse gas emission impacts of different corn ethanol plant types. Env Research Letter 2:1-9.

Zah R, Böni H, Gauch M, et al. 2008. Life cycle assessment of energy products: Environmental impact assessment of biofuels. EMPA, Technology and Society Lab, St. Gallen, Switz. www.empa.ch/tsl. 